\title{
Effect of irrigation levels and seed rates on wheat production
}

\author{
Wajid Ali Shah ${ }^{1}$, Zafar Hayat ${ }^{1}$, Roohul Amin ${ }^{1}$, Shazma Anwar ${ }^{2}$, \\ Muhammad Islam ${ }^{2 *}$, Anjum ${ }^{2}$ and Ikramullah ${ }^{3}$ \\ 1. Department of Agronomy, Bacha Khan University, Charsadda-Pakistan \\ 2. Department of Agronomy, The University of Agriculture, Peshawar-Pakistan \\ 3. Department of Plant Breeding and Genetics, Bacha Khan University, Charsadda-Pakistan \\ *Corresponding author's email: islamswati439@yahoo.com \\ Citation \\ Wajid Ali Shah, Zafar Hayat, Roohul Amin, Shazma Anwar, Muhammad Islam, Anjum and Ikramullah. Effect of \\ irrigation levels and seed rates on wheat production. Pure and Applied Biology. Vol. 5, Issue 4, pp895-905 \\ http://dx.doi.org/10.19045/bspab.2016.50113
}

Received: 12/02/2016

Revised: 28/07/2016

Accepted: 20/08/2016

Online First: 25/08/2016

\section{Abstract}

An experiment was carried out at Agricultural Research Station, Serai Nourang (District Bannu), Khyber Pakhtunkhwa-Pakistan to study the effect of irrigation levels and seed rates on wheat production. Experiment was laid out in a randomized complete block design with split plot arrangement having four replications. Five irrigation levels $\left(\mathrm{IL}_{1}=120, \mathrm{IL}_{2}=230, \mathrm{IL}_{3}=360, \mathrm{IL}_{4}=\right.$ 470 and $\left.\mathrm{IL}_{5}=600 \mathrm{~mm}\right)$ were allotted to main plots. While seed rates $\left(\mathrm{SR}_{1}=60, \mathrm{SR}_{2}=80, \mathrm{SR}_{3}=\right.$ $100, \mathrm{SR}_{4}=120$ and $\mathrm{SR}_{5}=140 \mathrm{~kg} \mathrm{ha}^{-1}$ ) were allocated to sub plots. The sub plot size was $4 \times 1.8$ $\mathrm{m}^{2}$ consisted six rows $30 \mathrm{~cm}$ apart. The fertilizer dose of $120 \mathrm{~kg} \mathrm{~N} \mathrm{ha}^{-1}$ and $90 \mathrm{~kg} \mathrm{~N} \mathrm{ha}^{-1}$ was applied in the form of Urea and DAP. Data recorded from the irrigation treatments revealed that maximum tillers $\mathrm{m}^{-2}$ (362), grains spike ${ }^{-1}$ (64), leaf area index (4.24), 1000-grains weight (43.19 g), grain yield (3130 kg ha-1), biological yield (13167 kg ha-1), net income (Rs. 44283), BCR $(3.71 \%)$ and MRR (370.82\%) was noted in plots irrigated with $470 \mathrm{~mm}$ water. Regarding seed rates, maximum tillers $\mathrm{m}^{-2}$ (346), grains spike ${ }^{-1}$ (62), leaf area index (4.08), 1000-grains weight (43.15 g), grain yield (3160 kg ha-1), biological yield (10403 $\left.\mathrm{kg} \mathrm{ha}^{-1}\right)$, net income (Rs. 39967), BCR (3.46\%) and MRR (345.95\%) was recorded in plots seeded with $120 \mathrm{~kg} \mathrm{ha}^{-1}$. In case of interaction between irrigation and seed rates, an increase was observed in tillers $\mathrm{m}^{-2}$, grains spike ${ }^{-}$ ${ }^{1}$, leaf area index, 1000-grains weight, grain yield, biological yield, net income, BCR and MRR up to $120 \mathrm{~kg} \mathrm{ha}^{-1}$ as seed rate and $470 \mathrm{~mm}$ water as irrigation. It was concluded that irrigation up to $470 \mathrm{~mm}$ and $120 \mathrm{~kg} \mathrm{ha}^{-1}$ seed rate gave better results and therefore recommended for better production of wheat.

Keywords: Wheat; Irrigation levels; Seed rates; Economical analysis

\section{Introduction}

Wheat requirement in Pakistan are growing at an exorbitant rate. Wheat being the staple food of general populace plays a vital role in socio-economic system of Pakistan. Being a major crop of Pakistan its average yield is too low when compared to that of advanced countries. During 2009-10, the average area, production and yield $\left(\mathrm{kg} \mathrm{ha}^{-1}\right)$ were 8447.90 (000 ha), 21276.80 (000 tones) and $2519 \mathrm{~kg}$ $\mathrm{ha}^{-1}$ respectively. In Khyber Pakhtunkhwa, the average area, production and yield $(\mathrm{kg}$ ha $^{-1}$ ) were 721.30 (000 ha), 1100.60 (000 tones) and $2553 \mathrm{~kg} \mathrm{ha}^{-1}$ [1]. Low yield of 
wheat in Khyber Pakhtunkhwa and Pakistan as a whole is attributed to various factors, such as lack of (a) optimum water requirement (b) balanced use of nitrogen fertilizer (c) optimum seeding density (d) good seed of high yielding varieties (e) proper cultural practices. Water deficits are also associated with increased grain protein content [2]. Irrigation, or any cultural practice that enhances yield potential, can decrease grain protein content because of dilution with carbohydrates if nitrogen availability is not increase commensurately [3]. Excess level of irrigation or irrigation in the absence of a yield increase decreased grain protein (apparently by leaching nitrogen below the root zone). In contrast, irrigation increased grain protein content in other cases, and irrigation can mobilize surface-applied fertilizer. Plant density is one of the major factors determining the ability of the crop to capture resources. It is of particular importance in wheat production because it is under the farmer's control in most cropping systems. Optimum plant densities vary greatly between areas according to climatic conditions, soil, sowing time, and varieties [4]. Consequently, there is value in defining relationships between density and wheat yield to establish optimum seeding rates for various regions [5]. Therefore keeping in view the importance of optimum utility of water and plant population, the current study was designed to investigate the effect of irrigation levels and seed rates on wheat production.

\section{Materials and methods}

Experiment was conducted to study the response of wheat to various irrigation levels and different seed rates at Agricultural Research Station, Serai Nourang (District Bannu), Khyber Pakhtunkhwa-Pakistan. The study was aimed to find out the optimum water amount, optimum seed rates with respect to growth stages of wheat for higher grain yield. Experiment was laid out in a randomized complete design with split plot arrangement having four replications. Five irrigation levels $\left(\mathrm{IL}_{1}=120, \mathrm{IL}_{2}=230, \mathrm{IL}_{3}=\right.$ $360, \mathrm{IL}_{4}=470$ and $\mathrm{IL}_{5}=600 \mathrm{~mm}$ ) were allotted to main plots. While seed rates $\left(\mathrm{SR}_{1}\right.$ $=60, \mathrm{SR}_{2}=80, \mathrm{SR}_{3}=100, \mathrm{SR}_{4}=120$ and $\mathrm{SR}_{5}=140 \mathrm{~kg} \mathrm{ha}^{-1}$ ) were allocated to sub plots. Sub plot size was $4 \times 1.8 \mathrm{~m}^{2}$ having six rows $30 \mathrm{~cm}$ apart. Wheat variety LakkiJ03 sown on a well prepared seedbed. Prior to sowing, a composite soil sample analyzed for physico-chemical properties. The fertilizer dose of $120 \mathrm{~kg} \mathrm{~N} \mathrm{ha}^{-1}$ and $90 \mathrm{~kg} \mathrm{P}$ $\mathrm{ha}^{-1}$ was applied in the form of Urea and DAP. The nitrogen was applied in two equal split doses. First dose (60 kg N ha $\left.{ }^{-1}\right)$ was applied to whole experimental plot uniformly with full dose of phosphorus at the time of land preparation. While $2^{\text {nd }}$ dose $60 \mathrm{~kg} \mathrm{~N} \mathrm{ha}^{-1}$ was applied at $2^{\text {nd }}$ irrigation. Data was collected on number of tillers $\mathrm{m}^{-2}$, grains spike $^{-1}$, leaf area index, thousand grains weight, biological and grain yields. Economical analysis was performed for net benefit comparisons. Number of tillers $\mathrm{m}^{-2}$ was recorded by counting the number of tillers $\mathrm{m}^{-2}$ in one meter length area of the three central rows in each sub plot and their mean was then calculated. For calculating grain spike $^{-1}$, five spikes treatment ${ }^{-1}$ were randomly selected in each sub plot and then their grains were counted and the average worked out. Leaf area index was calculated according to the following formula:

Leaf Area Index $(\mathrm{LAI})=\underline{\text { Leaf area of the plant }}$ Ground area

Ground area is the space occupied by each plant.

For 1000-grains weight, two samples of thousand grains were counted from threshed clean lot of each treatment, their weights were taken and then averaged. Similarly for biological yield four central rows were harvested, air dried, weighed and converted to $\mathrm{kg} \mathrm{ha}{ }^{-1}$. These four rows were threshed, 
cleaned, dried and weighed to record the grains yield.

Water Amount measurement ( $\left.\mathrm{kg} \mathrm{ha}^{-1} \mathbf{~ m m}^{-1}\right)$

Water flume was used to calculate the depth of applied irrigations. Water flume was installed in the water channel carrying water to the field. Time and height of the water flow was calculated for each main plot. Depth of the water applied to each main plot during irrigation was calculated using the following formula.

$\mathrm{Q}_{\mathrm{C}}=\mathrm{W}_{\mathrm{F}} \times \mathrm{H}_{\mathrm{C}}$

$\mathrm{D}_{\mathrm{W}}=\mathrm{Q}_{\mathrm{C}} \mathrm{X} \mathrm{T} /$ Area

Where,

$\mathrm{Q}_{\mathrm{C}}=$ Discharge of water through water flume in liters per second

$D_{\mathrm{W}}=$ depth of water applied to unit area

$\mathrm{W}_{\mathrm{F}}=$ Width of the water flume

$\mathrm{H}_{\mathrm{C}}=$ height of the water flow in the flume

$\mathrm{T}=$ Time taken to irrigate Unit Area

\section{Economic analysis}

The profound analysis is termed as marginal rate of return (MRR), which were calculated that each incremental increase in cost was obtain a given increase in net benefit. For example, $\mathrm{MRR}=95 \%$, which indicate that for every Rs.1.00 invested, one can expect to recover the Rs. 1.00 and obtain an additional Rs.0.95 [6].

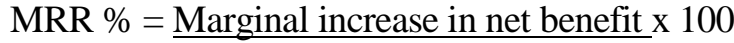
Marginal increase in cost

Benefit Cost Ratio $=$ Output $\left(\right.$ Rs ha $\left.^{-1}\right) /$ Input $\left(\right.$ Rs ha $\left.^{-1}\right)$ $\%$ Increase in benefit $=$ Individual benefit/total benefit $\mathrm{x} 100$ Net Income $=$ Total output - Total input

$\%$ Increase in cost $=$ Individual cost/total cost $\mathrm{x} 100$

(With the increase in total cost, there is increase in net income. but when the total cost exceeds the net income or with the increase in total cost, there is decrease in net income, and then it is called dominated treatments).

\section{Statistical analysis}

Statistical analysis of the two years data was done at $1 \%$ level of probability using Duncan's Multiple Range Test (DMRT) to test the difference between the individual means [7].

\section{Results}

Number of tillers $\mathbf{m}^{-2}$

Irrigation levels and seed rates had significant effect on tillers $\mathrm{m}^{-2}$ (Table 1). Maximum tillers $\mathrm{m}^{-2}$ (362) were noted for plots treated with $470 \mathrm{~mm}$ of water (IL4), followed by plots treated with $600 \mathrm{~mm}$ water (355) $\mathrm{IL}_{5}$, which was statistically similar to $\mathrm{IL}_{4}$ while minimum tillers $\mathrm{m}^{-2}$ (250) were produced when plots were irrigated with $120 \mathrm{~mm}$ of water $\left(\mathrm{IL}_{1}\right)$. Similarly in case of seed rates, maximum tillers $\mathrm{m}^{-2}$ (346) were counted when plots were seeded with $120 \mathrm{~kg} \mathrm{ha}^{-1}\left(\mathrm{SR}_{4}\right)$, while minimum tillers $\mathrm{m}^{-2}$ (299) were recorded when $60 \mathrm{~kg} \mathrm{ha}^{-1}$ seed rate was used $\left(\mathrm{SR}_{1}\right)$. Regarding interaction between irrigation levels and seed rates, maximum tillers $\mathrm{m}^{-2}$ were noted when water was used at the rate of $470 \mathrm{~mm}$ and $120 \mathrm{~kg} \mathrm{ha}^{-1}$ seed rate was used ( $\left.\mathrm{IL}_{4} \mathrm{SR}_{4}\right)$, while less tillers $\mathrm{m}^{-2}$ were noted from plots when $120 \mathrm{~mm}$ water was applied and seeded with 60, 80 and $100 \mathrm{~kg}$ $\mathrm{ha}^{-1}$ which were statistically similar $\mathrm{IL}_{1} \mathrm{SR}_{1}$, $\mathrm{IL}_{1} \mathrm{SR}_{2}, \mathrm{IR}_{1} \mathrm{SR}_{3}$ (Figure 1a).

Number of grains spike ${ }^{-1}$

The potential of wheat spike is determined by the number of grains spike ${ }^{-1}$ which is an important yield component of grain yield. The data on number of grains spike $^{-1}$ of wheat significantly influenced by different irrigation levels and seed rates are presented in Table 1. Maximum grains spike ${ }^{-1}$ (64) were recorded from plots treated with 470 $\mathrm{mm}$ water $\left(\mathrm{IL}_{4}\right)$, while less grains spike $^{-1}$ (51) were recorded when $120 \mathrm{~mm}$ water $\left(\mathrm{IL}_{1}\right)$ was given. The data also revealed that in seed rates, more grains spike ${ }^{-1}$ (62) were produced when plots were seeded with 120 $\mathrm{kg} \mathrm{ha}^{-1}$ seed rate $\left(\mathrm{SR}_{4}\right)$, whereas less number of grains spike ${ }^{-1}(54)$ were noted with $60 \mathrm{~kg}$ $\mathrm{ha}^{-1}$ seed rate $\left(\mathrm{SR}_{1}\right)$. The data further showed that interaction between irrigation levels and seed rates (IL x SR) was found significant. Maximum number of grains spike ${ }^{-1}$ were noted when water was used at the rate of 
$470 \mathrm{~mm}$ and seeded with $120 \mathrm{~kg} \mathrm{ha} \mathrm{ha}^{-1}$ ( $\mathrm{IL}_{4} \mathrm{SR}_{4}$ ), while minimum number of grains spike $^{-1}$ were recorded from plots when 120 $\mathrm{mm}$ water was applied and $60 \mathrm{~kg} \mathrm{ha}^{-1}$ seed rate used ( $\mathrm{IL}_{1} \mathrm{SR}_{1}$, Figure $\left.1 \mathrm{~b}\right)$.

\section{Leaf area index}

Leaf area index is used as an indicator of plant growth and development for evaluating assimilation and transpiration rates in plant physiological studies. It ultimately affects the yield attributes and grain yield of wheat. A significant influence in LAI of wheat by irrigation levels and seed rates is reported Table 1 . Statistical analysis of the data showed that maximum leaf area index (4.24) was recorded in plots treated with $470 \mathrm{~mm}$ of water (IL4) followed by the plots treated with $600 \mathrm{~mm}$ of water (IL5), while minimum leaf area index (2.58) was recorded when plots were irrigated with 120 $\mathrm{mm}$ of water $\left(\mathrm{IL}_{1}\right)$. Regarding seed rates maximum leaf area index (4.08) was noted when plots were seeded with $120 \mathrm{~kg} \mathrm{ha}^{-1}$ $\left(\mathrm{SR}_{4}\right)$, while minimum leaf area index (3.24) were recorded with $60 \mathrm{~kg}$ seed rate ha ${ }^{-1}$ $\left(\mathrm{SR}_{1}\right)$. The data also indicated that interaction between irrigation levels and seed rate was found significant (Figure 1c). Maximum leaf area index was noted when water was used at the rate of $470 \mathrm{~mm}$ and seeded with $120 \mathrm{~kg} \mathrm{ha}^{-1}\left(\mathrm{IL}_{4} \mathrm{SR}_{4}\right)$, while minimum leaf area index was recorded from plots when $120 \mathrm{~mm}$ water was applied and $60 \mathrm{~kg} \mathrm{ha}^{-1}$ seed rate used ( $\left.\mathrm{IL}_{1} \mathrm{SR}_{1}\right)$.

Table 1. Number of tillers $\mathbf{m}^{-2}$, number of grains spike ${ }^{-1}$ and leaf area index of wheat as affected by seed rates and irrigation levels

\begin{tabular}{|c|c|c|c|}
\hline Treatments & $\begin{array}{l}\text { Number of } \\
\text { tillers } \mathbf{m}^{-2}\end{array}$ & $\begin{array}{c}\text { Number of } \\
\text { grains spike }^{-1}\end{array}$ & $\begin{array}{c}\text { Leaf area } \\
\text { Index }\end{array}$ \\
\hline \multicolumn{4}{|c|}{ Seed rates(SR = kg ha-1) } \\
\hline $\mathrm{SR} 1=60$ & $299.35 \mathrm{~d}$ & $54.25 \mathrm{~d}$ & $3.24 \mathrm{~d}$ \\
\hline SR2 $=80$ & $312.90 \mathrm{c}$ & $58.55 \mathrm{c}$ & $3.57 \mathrm{bc}$ \\
\hline $\mathrm{SR} 3=100$ & $317.65 \mathrm{c}$ & $60.70 \mathrm{~b}$ & $3.62 \mathrm{~b}$ \\
\hline SR4 = 120 & $346.10 \mathrm{a}$ & $62.70 \mathrm{a}$ & $4.08 \mathrm{a}$ \\
\hline $\mathrm{SR} 5=140$ & $331.20 \mathrm{~b}$ & $57.80 \mathrm{c}$ & $3.37 \mathrm{~cd}$ \\
\hline LSD Value & 10.08 & 1.63 & 0.22 \\
\hline \multicolumn{4}{|c|}{ Irrigation levels $(\mathrm{IL}=\mathbf{m m})$} \\
\hline IL1 $=120$ & $250.30 \mathrm{~d}$ & $51.20 \mathrm{c}$ & $2.58 \mathrm{~d}$ \\
\hline IL2 $=230$ & $306.55 \mathrm{c}$ & $55.95 \mathrm{bc}$ & $3.30 \mathrm{c}$ \\
\hline IL3 $=360$ & $332.70 \mathrm{~b}$ & $58.65 \mathrm{ac}$ & $3.65 \mathrm{~b}$ \\
\hline $\mathrm{IL} 4=470$ & $362.35 \mathrm{a}$ & $64.80 \mathrm{a}$ & $4.24 \mathrm{a}$ \\
\hline IL5 $=600$ & $355.30 \mathrm{a}$ & $63.40 \mathrm{ab}$ & $4.12 \mathrm{a}$ \\
\hline LSD Value & 8.68 & 8.83 & 0.22 \\
\hline \multicolumn{4}{|c|}{ LSD Value for interaction } \\
\hline SR x IL & $*$ & $*$ & $*$ \\
\hline
\end{tabular}

Means in the same category followed by different letters are significantly different at $\mathrm{P} \geq 0.05$ levels. ${ }^{*}=$ significant 

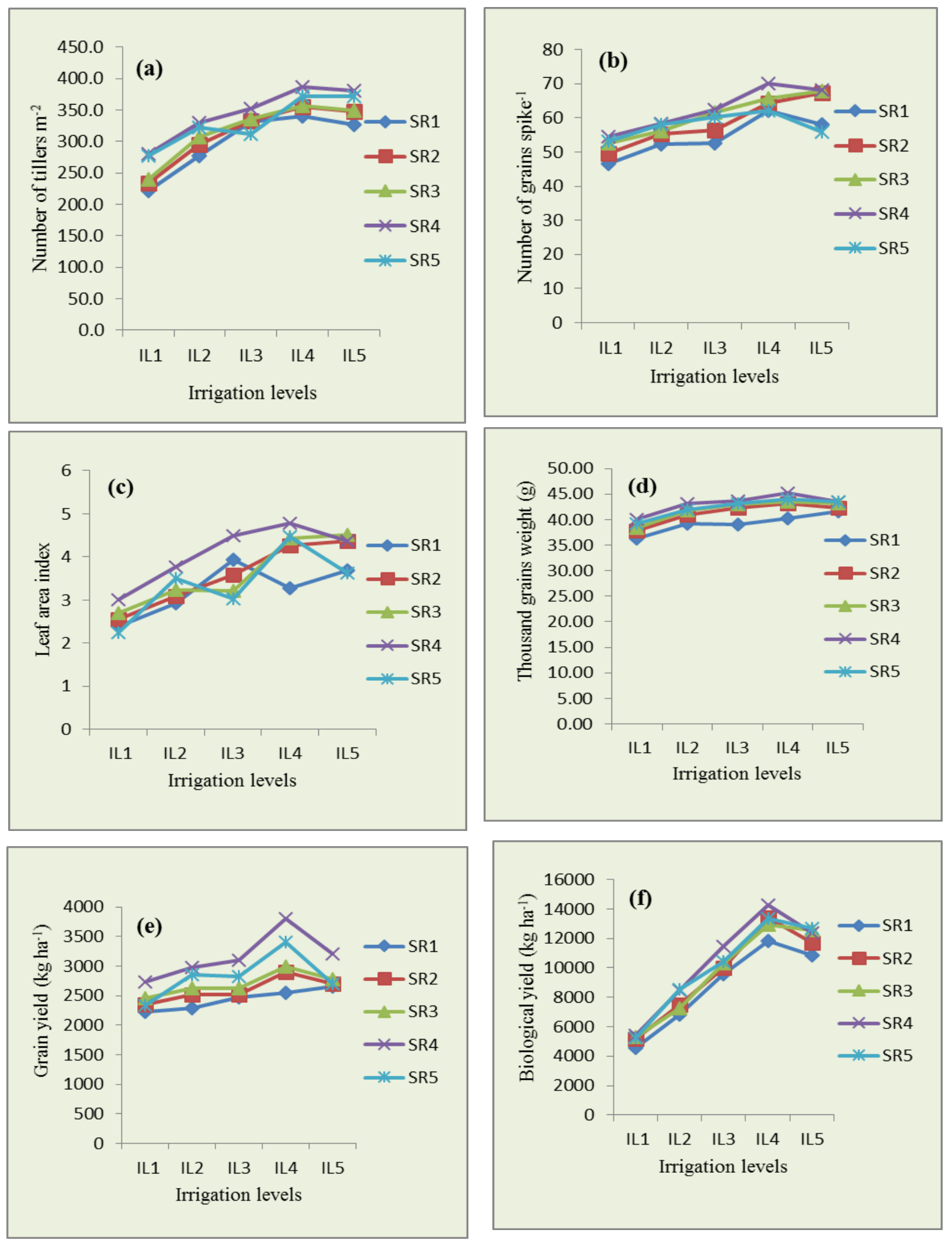

Figure 1. Tillers $\mathrm{m}^{-2}$, grains spike ${ }^{-1}$, leaf area index, thousand grains weight, grain yield and biological yield of wheat as affected by seed rates and irrigation levels 


\section{Thousand grains weight (g)}

It can be inferred from the data showed in Table 2 indicated that 1000-grain weight of wheat was significantly affected by irrigation levels and also by the seed rates. Statistical analysis of the data showed that maximum 1000-grains weight (43.19 g) was recorded when plots were irrigated with 470 $\mathrm{mm}$ water $\left(\mathrm{IL}_{4}\right)$, followed by plots treated with $600 \mathrm{~mm}$ water, while minimum $(38.38$ g) were produced from those plots treated with $120 \mathrm{~mm}$ water $\left(\mathrm{IL}_{1}\right)$. In case of seed rates, heavier grains $(43.15 \mathrm{~g})$ were produced when plots were seeded with 120 $\mathrm{kg} \mathrm{ha}^{-1}$ seed rate $\left(\mathrm{SR}_{4}\right)$, while lighter grains (39.30 g) were noted with $60 \mathrm{~kg} \mathrm{ha}^{-1}$ seed rate $\left(\mathrm{SR}_{1}\right)$. The data further showed that interaction between irrigation levels and seed rate was significantly affected 1000grains weight (Figure 1d). It is clear from the data that during maximum 1000-grains weight were noted when water was used at the rate of $470 \mathrm{~mm}$ and seeded with $120 \mathrm{~kg}$ $\mathrm{ha}^{-1}\left(\mathrm{IL}_{4} \mathrm{SR}_{4}\right)$, while minimum was recorded from plots when $120 \mathrm{~mm}$ water was applied and $60 \mathrm{~kg} \mathrm{ha}^{-1}$ seed rate used $\left(\mathrm{IL}_{1} \mathrm{SR}_{1}\right)$.

Grains yield ( $\mathrm{kg} \mathrm{ha}^{-1}$ )

Grain yield in wheat is the ultimate goal towards which all the efforts are directed. Data presented in Table 2 indicated that irrigation levels and seed rates had significant effect on grain yield of wheat. Maximum grain yields (3130 $\left.\mathrm{kg} \mathrm{ha}^{-1}\right)$ was recorded in plots treated with $470 \mathrm{~mm}$ water (IL4), while minimum grain yield $(2417 \mathrm{~kg}$ $\mathrm{ha}^{-1}$ ) was recorded when $120 \mathrm{~mm}$ water $\left(\mathrm{IL}_{1}\right)$ was given to the plot. Regarding seed rates, maximum grain yield $\left(3160 \mathrm{~kg} \mathrm{ha}^{-1}\right)$ was produced when plots were seeded with $120 \mathrm{~kg} \mathrm{ha}^{-1}\left(\mathrm{SR}_{4}\right)$, while minimum grain yield $\left(2437 \mathrm{~kg} \mathrm{ha}^{-1}\right)$ was noted with $60 \mathrm{~kg}$ $\mathrm{ha}^{-1}$ seed rate $\left(\mathrm{SR}_{1}\right)$. It was also cleared from statistical analysis of data that IL $x$ SR interaction significantly affected grain yield of wheat (Figure 1e). Maximum grain yield was noted when water was used at the rate of $470 \mathrm{~mm}$ and seeded with $120 \mathrm{~kg} \mathrm{ha}^{-1}$ (IL4 $\mathrm{SR}_{4}$ ), while minimum was recorded from plots when $120 \mathrm{~mm}$ water was applied and $60 \mathrm{~kg} \mathrm{ha}^{-1}$ seed rate was used $\left(\mathrm{IL}_{1} \mathrm{SR}_{1}\right)$.

\section{Biological yield ( $\mathrm{kg} \mathrm{ha}^{-1}$ )}

Table 2 presents data regarding biological yield of wheat. It was revealed from statistical analysis that irrigation levels, and IL $x$ SR interaction significantly affected biological yield of wheat, whereas the effect of seed rates was found non-significant. Maximum biological yield (13167 kg ha-1) was recorded when plots were irrigated with $470 \mathrm{~mm}$ water $\left(\mathrm{IL}_{4}\right)$, while minimum (5137 $\mathrm{kg} \mathrm{ha}{ }^{-1}$ ) was produced from those plots supplied with $120 \mathrm{~mm}$ water $\left(\mathrm{IL}_{1}\right)$. In case of interaction between irrigation levels and seed rates, maximum biological yield was noted when water was used at the rate of $470 \mathrm{~mm}$ and seeded with $120 \mathrm{~kg} \mathrm{ha}^{-1}$ ( $\mathrm{IL}_{4} \mathrm{SR}_{4}$ ), while minimum was recorded from plots when $120 \mathrm{~mm}$ water was applied and $60 \mathrm{~kg} \mathrm{ha}^{-1}$ seed rate used (Figure 1a \&f). 
Table 2. Thousand grains weight, grains yield and biological yield of wheat as affected by seed rates and irrigation levels

\begin{tabular}{|c|c|c|c|}
\hline Treatments & $\begin{array}{c}\text { Thousand grains } \\
\text { weight (g) }\end{array}$ & $\begin{array}{c}\text { Grains yield (kg } \\
\text { ha }^{-1} \text { ) }\end{array}$ & $\begin{array}{c}\text { Biological yield } \\
\left(\mathrm{kg} \mathrm{ha}^{-1}\right)\end{array}$ \\
\hline \multicolumn{4}{|c|}{ Seed rates(SR = kg ha-1) } \\
\hline SR1 $=60$ & $39.30 \mathrm{~d}$ & $2437 \mathrm{c}$ & 8735 \\
\hline SR2 $=80$ & $41.31 \mathrm{c}$ & $2599 \mathrm{bc}$ & 9568 \\
\hline SR3 $=100$ & $41.95 \mathrm{bc}$ & $2695 \mathrm{~b}$ & 9664 \\
\hline $\mathrm{SR} 4=120$ & $43.15 \mathrm{a}$ & $3160 \mathrm{a}$ & 10403 \\
\hline SR5 $=140$ & $42.35 \mathrm{~b}$ & $2821 \mathrm{~b}$ & 10045 \\
\hline LSD Value & 0.72 & 232.5 & $\mathrm{Ns}$ \\
\hline \multicolumn{4}{|c|}{ Irrigation levels $(\mathrm{IL}=\mathrm{mm})$} \\
\hline $\mathrm{IL} 1=120$ & $38.38 \mathrm{~d}$ & $2417 \mathrm{c}$ & $5137 \mathrm{~d}$ \\
\hline IL2 $=230$ & $41.43 \mathrm{c}$ & $2650 \mathrm{bc}$ & $7727 \mathrm{c}$ \\
\hline IL3 $=360$ & $42.22 \mathrm{~b}$ & $2710 \mathrm{~b}$ & $10344 \mathrm{~b}$ \\
\hline IL4= 470 & $43.19 \mathrm{a}$ & $3130 \mathrm{a}$ & $13167 \mathrm{a}$ \\
\hline IL5= 600 & $42.85 \mathrm{a}$ & $2805 \mathrm{~b}$ & $12041 \mathrm{ab}$ \\
\hline LSD Value & 0.51 & 254.3 & 1705 \\
\hline \multicolumn{4}{|c|}{ LSD Value for interaction } \\
\hline SR x IL & $*$ & $*$ & $*$ \\
\hline
\end{tabular}

Means in the same category followed by different letters are significantly different at $\mathrm{P} \geq 0.05$ levels. $*=$ significant

Table 3. Detail of irrigation levels maintained in the experiment

\begin{tabular}{|l|l|l|c|}
\hline Treatments & $\begin{array}{l}\text { Irrigation Days after } \\
\text { sowing }\end{array}$ & Water amount used (mm) & $\begin{array}{l}\text { Total amount of } \\
\text { water (mm) }\end{array}$ \\
\hline $\mathrm{IL}_{1}$ & $15-110$ & $50+70$ & 120 \\
\hline $\mathrm{IL}_{2}$ & $15-40-110$ & $70+90+70$ & 230 \\
\hline $\mathrm{IL}_{3}$ & $15-40-90$ & $120+110+130$ & 360 \\
\hline $\mathrm{IL}_{4}$ & $15-40-90-110$ & $120+110+130+110$ & 470 \\
\hline $\mathrm{IL}_{5}$ & $15-40-90-110+138$ & $120+110+130+110+130$ & 600 \\
\hline
\end{tabular}

\section{Economic analysis}

Net income, benefit cost ratio (BCR) and marginal rate of return (MRR \%) showed a significant increase (Fig: 2 \& 3). Maximum when plots were treated with $470 \mathrm{~mm}$ water and gave Rs. 44283.00 net profit as compared to other treatment, similarly minimum (Rs. 22974.00) net profit from the plots irrigated @120 mm water. Data also indicate that plots seeding $120 \mathrm{~kg} \mathrm{ha}^{-1}$ recorded huge net profit (Rs. 39967.00) as compared to plots in which seed rate was used @ 60 kg ha ${ }^{-1}$ produced low net profit (Rs. 29091.00). When the interaction was studied, it was noted that combination of $470 \mathrm{~mm}$ and $120 \mathrm{~kg} \mathrm{ha}^{-1}$ seed rate record maximum (Rs. 54043.00) net profit. Minimum net profit was gained when 120 $\mathrm{mm}$ water was supplied and seeded with 60 $\mathrm{kg} \mathrm{ha}^{-1}$ (Rs. 20177.00). When the BCR (benefit cost ratio) was studied, it was observed that irrigation levels showed a significant increase. Maximum (3.71) BCR was noted when plots were irrigated with $470 \mathrm{~mm}$ of water, while minimum (2.53) BCR was recorded from the plots treated with $120 \mathrm{~mm}$ water. In case of seed rate treatments, highest BCR was noted when 
plots were seeded with $120 \mathrm{~kg} \mathrm{ha}^{-1}$ (3.46), while lowest (2.53) BCR was recorded from those plots in which seed rate was used @ $60 \mathrm{~kg} \mathrm{ha}^{-1}$. The data further revealed that interaction between irrigation and seed rate was significantly affected. Maximum BCR (4.26) was observed when $470 \mathrm{~mm}$ water was applied and seeded with $120 \mathrm{~kg} \mathrm{ha}^{-}$ ${ }^{1}$.Minimum BCR was noted from the plots 2.39 was noted when plots were irrigated @ $120 \mathrm{~mm}$ and $60 \mathrm{~kg} \mathrm{ha}^{-1}$ seed rate was used. The profound analysis is termed as marginal rate of return (MRR), which were calculated that each incremental increase in cost was obtain a given increase in net benefit. It is clear from the data that highest MRR \% was noted from the plots irrigated with $470 \mathrm{~mm}$ of water (370.82), while lowest MRR \% was recorded from those plots which were treated with $120 \mathrm{~mm}$ water (252.88). When the seed rate treatments were studied, it was noted that plots seeded with $120 \mathrm{~kg} \mathrm{ha}^{-1}$ produced maximum (345.94) MRR \%. Minimum (287.29) MRR \% was noted from those plots seeded with $60 \mathrm{~kg} \mathrm{ha}^{-1}$. In case of interaction, maximum (352.15) MRR \% was noted in the combination of $470 \mathrm{~mm}$ water and $120 \mathrm{~kg} \mathrm{ha}^{-}$ 1 seed rate, while minimum MRR \% was recorded from the plots irrigated with 120 $\mathrm{mm}$ water and seeded with $60 \mathrm{~kg} \mathrm{ha}^{-1}$ (238.77). Form the economical results, it is concluded that always don't increase water from $470 \mathrm{~mm}$, because the yield and yield components will affected as well as the extra water will be loss, due to insufficient utilization and it will directly affect economic condition of the farmer. $120 \mathrm{~kg} \mathrm{ha}^{-1}$ seed rate is recommended as we use huge amount of seed rate, then due to inter and intra plant competition, the yield will decrease and also economical loss (Table 3).

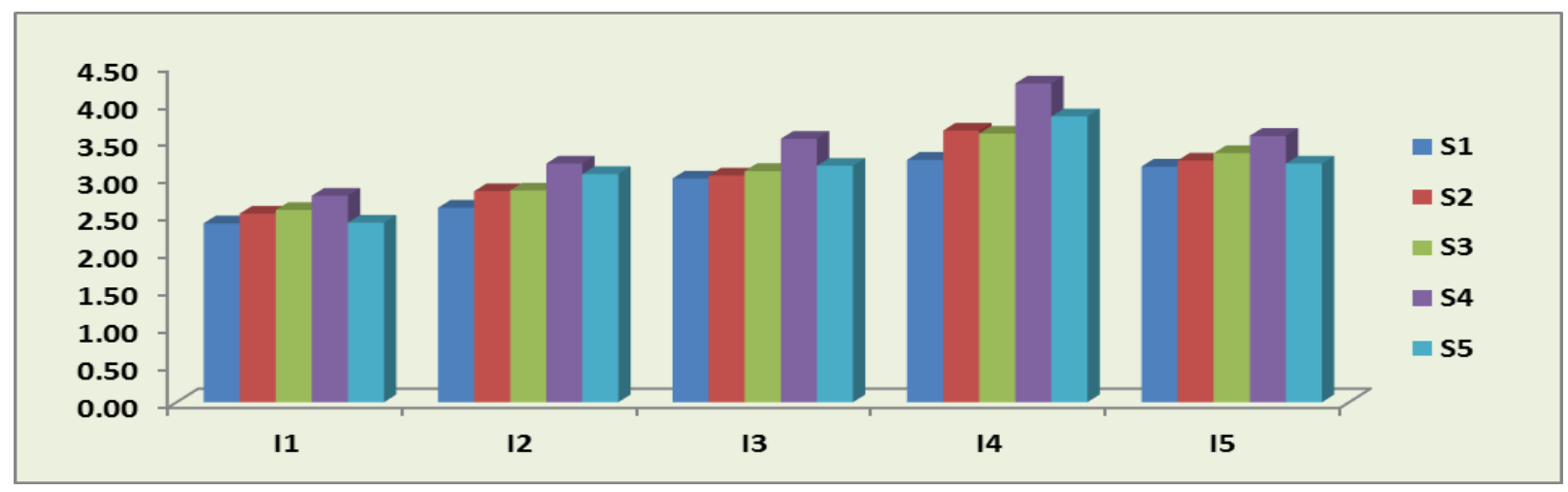

Figure 3. Net Income of wheat as affected by irrigation levels and different seed rates

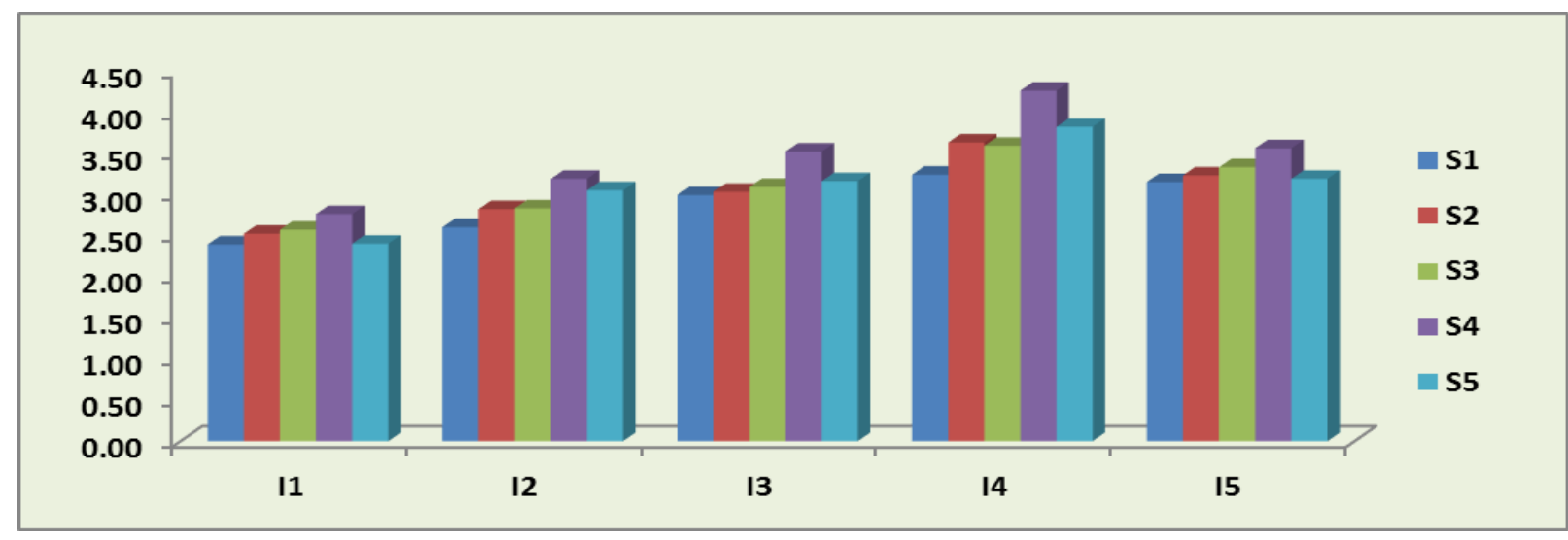

Figure 4. Marginal Rate of Return of wheat as affected by irrigation levels and different seed rates 


\section{Discussion}

Irrigation levels had significant effect on tillers $\mathrm{m}^{-2}$. These results are in conformity with $[8,9]$ who obtained maximum tillers by increasing irrigation levels. Different seed rates significantly affected tillers $\mathrm{m}^{-2}$. These results are also reported by $[10,11]$ who found maximum tillers at higher seed rates than at lower seed rates. The interaction between irrigation levels and seed rate was also found significantly affected. The tillering potential was much higher at higher seed rate, when compared to lower seed rate. It might be due to that the number of tillers $\mathrm{m}^{-2}$ decreased with increase in seeding rate, because, by increasing seed rate per unit area, the inter plant competition for space, nutrient, moisture and sun light increases which results in lower tillers $\mathrm{m}^{-2}$.

The potential of wheat spike is determined by the number of grains spike ${ }^{-1}$ which is an important yield component of grain yield. Data showed that irrigation levels had significant effect on grains spike ${ }^{-1}$. The reason could be the low water stress in plot which received the higher number of irrigation. It could be due to the shortage of $\mathrm{H}_{2} \mathrm{O}$ that less numbers of grains were produced with the application of $\mathrm{IL}_{1}$ treatments. [12] stated that highest number of grains spike $^{-1}$ was recorded for 4 irrigations and lowest for 2 irrigations. The data also revealed that different seed rate significantly affected number of grains spike $^{-1}$. The increase in grains spike ${ }^{-1}$ with decrease in seed rate might be due to the plant nutrients present in the soil were enough for the vegetative growth and grain formation because of less number of plants per unit area. Similar results were also reported by [13], who reported that higher seed rates produced significant decrease in the number of grains spike ${ }^{-1}$. The data further showed that interaction between irrigation levels and seed rate was found significant. Similar results were also reported by [14], who stated that at highest levels of irrigation and seed rate, plant population was also high which created a sort of competition for space and nutrition and outcome was a reduction of number of grains spike ${ }^{-1}$.

Leaf area index is used as an indicator of plant growth and development for evaluating assimilation and transpiration rates in plant physiological studies ultimately affect the yield attributes and grain yield of wheat. The increase in leaf area index with irrigation is due to increase in tillers $\mathrm{m}^{-2}$ and leaf area tiller ${ }^{-1}$. Both of these characters as well as leaf area index may have been increased due to increased water availability that affect cell division and cell enlargement. These results are in agreement with [15] reported that maximum leaf area index was noted when nitrogen was used @110 kg ha-1. The data further showed that different seed rate had significantly affected leaf area index. This might be due to long vegetation growth in low seeded plots than higher seeded ones. The seeding rate at $140 \mathrm{~kg} \mathrm{ha}^{-1}$ decreased the leaf area index due to greater competition among the plants for the limited sunlight and available nutrients in the soil. Similar results were also reported by [16]. The data also indicated that interaction between irrigation levels and seed rate was found significant. It might be due to greater competition among the plants to the limited sunlight and available nutrients in the soil for Leaf area index. As leaf area index depend upon tillers $\mathrm{m}^{-2}$ and leaf area tiller ${ }^{-1}$, the differences in leaf area of the crop under different irrigation and seed rates may be due to interaction of internal genetic factors with environmental factor especially light and water status of the soil.

Data indicated that 1000-grain weight was significantly affected various irrigation levels. This may be due to that lower seeding rates produce a high proportion of 
secondary tillers, which may be more prone to producing small grain. This is attributed to higher temperature and water stress during grain filling than the earlier forming primary tillers. These results are in conformity with [17] who reported that grain weight can be increased by increasing irrigation levels. [13] stated that water stress caused premature grain desiccation and resulted in a marked decline in grain sucrose and reduced grain weight. The data also revealed that different seed rate had significantly effect on 1000-grain weight. It may be due to the variation in spikes $\mathrm{m}^{-2}$, because as spikes population increase, the amount of assimilates to be translocated to spike by each plant per unit area decrease and thus resulted in less 1000 grain weight under light seeding densities. The results obtained agree with findings of [18], who also reported that 1000 grain weight decreased with increasing in seeding densities. The data further showed that interaction between irrigation levels and seed rate was significantly affected 1000grains weight. Identical findings were reported by [2]. The loss in yield due to water deficit during the flowering period cannot be recovered by providing adequate water supply during the later growth period.

Grain yield in wheat is the ultimate goal towards which all the efforts are directed. Statistical analysis of the data indicated that irrigation levels had significant effect on grain yield. These results are in agreement with [17] who stated that wheat with 4 irrigations gave $64.50 \%$ more grain yield than the crop with $3\left(2128 \mathrm{~kg} \mathrm{ha}^{-1}\right)$ and 2 (1646 kg ha-1) irrigation respectively. The data also revealed that different seed rate had significant effect on grain yield. These results are in agreement with [16, 20] who reported that grain yield increased as seed rate increased and the highest grain yield was produced by plots seeded at the rate of $120 \mathrm{~kg} \mathrm{ha}^{-1}$. Analysis of data further showed that interaction between irrigation levels and seed rate was significantly affected grain yield. These results are in agreement with [21].

Biological yield is an important parameter because farmers are also interested in straw in addition to grain. It can be inferred from the data showed that biological yield was significantly affected various irrigation levels. These results are in conformity with [13] reported that straw yield increased when the number of irrigations increased from 2 to 4 but further increase showed negative effect. Data indicated that seed rate had non-significant effect on biological yield of wheat. The biological yield was significantly affected by seed rate. Similar trend was observed in pooled analysis of two years data. These results are in agreement with [2] who stated that the increase in biological yield with higher seed rate might be due to more number of plants per unit area. Analysis of data further showed that interaction between irrigation levels and seed rate was significantly affected biological yield. Similar results were also reported by [14]. Biological yield is a product of number of tillers $\mathrm{m}^{-2}$ and tillers weight including spike weight and grain weight. The differences in biological yield could be variation in tillers $\mathrm{m}^{-2}$ and tiller weight.

\section{Authors' contributions}

Conceived and designed the experiments: WA Shah \& S Anwar, Performed the experiments: WA Shah, Analyzed the data: WA Shah, Z Hayat \& R Amin, Statistical analysis of the data: WA Shah, S Anwar, M Islam \& Anjum, Contributed reagents/ materials/ analysis tools: Z Hayat, R Amin \& Ikramullah, Wrote the paper: WA Shah \& M Islam.

\section{References}

1. Ministry of Food, Agriculture and cooperatives. 2010. Agricultural statistics of Pakistan. Government of Pakistan, Ministry of Food, Agricultural and 
cooperatives, food and agricultural division (economic wing) Islamabad.

2. Ejaz AW, Ahmad R, Anser A \& Ullah S (2007). Irrigation and nitrogen effects on grain development and yield in wheat (Triticum aestivum L.). Pak J Bot 39(5): 1663-1672.

3. Eck HV (1988). Winter wheat response to $\mathrm{N}$ and irrigation. Agron J 80: 902-908.

4. Khurram S, Bakht J, Shafi M, Wajid SA \& Jabeen N (2002). Yield and yield component of various wheat varieties as affected by different sowing dates. Asian J Plant Sci 1: 522-525.

5. Ejaz H, Taj FH, Bakht J, Wajid SA \& Shad AA (2002). Yield and yield components of wheat as affected by different planting dates seed rate and nitrogen levels. Asian J Plant Sci 1(5): 502-506.

6. CIMMYT (1988). An economic training manual; from agronomic data to farmer recommendations. Mexico. 1-25.

7. Steel RGD \& Torrie JH (1984). Principles and procedures of statistics. McGraw Hill Book Co., Inc., Singapore: 172-177.

8. Niaz A, Saqib R, Ramzan M \& Nauman Q (1996). Impact of management practices in reuse of subsurface drainage water. Proceedings of 6th drainage workshop on drainage and the environment, Ljubljana, Slovenia, April.

9. Singh S \& Bhan VM (1998). Response of wheat (Triticum aestivum L.) and associated weeds to irrigation regime, nitrogen and 2,4-D. Indian J Agron 43(4): 662-667.

10. Youn EB, Yoon YH, Kwon YU, Yoon KB \& Shin MG (1991). Studies on fertilizer levels, row spacing and sowing rate using the plot drill seeder in winter wheat. Res. Res. Rural Development In, Upland and Industrial Crops, 33: 65-71.

11. Hasan K \& Songul G (2010). Effect of seeding rate on yield and yield components of durum wheat cultivars in cotton-wheat cropping system. Sci Res \& Ess 5(15): 2078-2084.
12. Khan MJ, Tahir S, Aneela S \& Abdul M (2007). Effect of different irrigation schedules on water use and yield of wheat. Sarhad J Agric 23(4): 1061-1067.

13. Kabir, Khan AR, Islam MA \& Haque MR (2009). Effect of seed rate and irrigation level on the performance of wheat cv. Gourab J Bangladesh Agri Univ 7(1): 4752.

14. Naeem S, Maqsood M, Mubeen K, Shehzad M, Bhullar MS, Qamar R \& Akbar N (2010). Effect of different levels of irrigation on yield and yield components of wheat cultivars. Sarhad J Agric 26(2):

15. Aslam MZ, Rahman MS, Haque ME, Hossain MS, Azad MAK \& Khan MRH (2003). Response of irrigation frequencies and different doses of $\mathrm{n}$ fertilization on the growth and yield of wheat. Pak J Bio Sci 6 (8): 732-734.

16. Ibrar K (1999). Effect of seed rates and nitrogen levels on wheat. M.Sc. (Hons) Thesis, Deptt. Agro. The Univ. Agric. Peshawar, Pakistan.

17. Wang Xiao-ying, Ming-rong HE, Li Fei, Younghuan LIU, Hong-hua Z \& Chungang LIU (2010). Coupling effects of irrigation and nitrogen fertilizer on grain protein and starch quality of strong-gluten winter wheat.

18. Ibal N, Akbar N., Ali M, Sattar M \& Ali L (2010). Effect of seed rates and row spacing on yield and yield components of wheat (Triticum aestivum L.). Pak J Agri Sci 47(3): 371-374.

20. Laghari GM, Oad FC, Tunio S, Chachar Q, Ghandahi AW \& Siddiqui $\mathrm{MH}$ (2011). Growth and yield attributes of wheat at different seed rates. Sarhad $J$ Agric 27(2): 177-183.

21. Jaime L, Manent J, Viudas J, Lopez A \& Santiveri P (2004). Seeding rate influence on yield and yield components of irrigated winter wheat in a Mediterranean Climate. Agron $J$ 96: 1258-1265. 